\title{
HELICOBACTER PYLORI GENOTYPES AMONG BELARUS PATIENTS WITH GASTRODUODENAL DISORDERS AND THEIR ASSOCIATION WITH CLINICAL OUTCOME
}

\author{
Olga YANOVICH $^{1 *}$, MichaIL DoroshKo ${ }^{2}$ and LeONID Titov ${ }^{1}$ \\ ${ }^{1}$ Laboratory for Clinical and Experimental Microbiology, The Republican Scientific and \\ Practical Center for Epidemiology and Microbiology, Minsk, Belarus \\ ${ }^{2}$ Diagnostic Department, Medical Center "Nordin”, Minsk, Belarus
}

(Received: 6 March 2019; accepted: 10 April 2019)

\begin{abstract}
The aim of this study was to evaluate the prevalence of Helicobacter pylori genotypes (vacA and cagPAI) directly in gastric biopsy specimens in patients with gastric diseases in Belarus. Gastric biopsies were collected from 461 patients with different gastrointestinal disorders: superficial gastritis (287 subjects), atrophy gastritis (59 subjects), erosive gastritis (47 subjects), duodenal ulcer disease (54 subjects), and stomach ulcer (14 subjects). PCR-based genotyping was used to detect $s 1 a, s 1 b, s 2$, $m 1 a, m 1 b, m 2, \operatorname{cag} M, \operatorname{cag} A$, and $\operatorname{cag} T$ genes. Overall prevalence of $v a c A$ sla allele was $60.5 \%$ followed by $m 2(47.1 \%)$ and $m 1 a(37.5 \%)$. The analysis of data showed that genotype $s 1 a /$ mla was significantly more prevalent in patients with duodenal ulcer $(21.4 \%$ vs. $45.1 \%, \mathrm{OR}=3.0,95 \% \mathrm{CI}=1.5-6.1)$. The cag $A$ gene was found with a high incidence in most patients with inflammatory diseases of stomach and duodenum. There was a significant increase in the frequency of $\operatorname{cag} T$ in patients with duodenal ulcer as compared to superficial gastritis. A high $\operatorname{cag} M$ prevalence was found in patients with atrophy gastritis and duodenal ulcer disease. All three island genes of pathogenicity of cagPAI are more often detected in patients with duodenal ulcer, which increases the risk of developing duodenal ulcer by 4.5 times.
\end{abstract}

Keywords: Helicobacter pylori genotypes, clinical outcome, cagPAI

\section{Introduction}

Helicobacter pylori $(H P)$ is possibly the most widespread human pathogen that causes of gastritis, peptic ulceration, and gastric cancer. According to World Health Organization statistics, $H P$ is reported as a class 1 carcinogen in gastric adenocarcinoma [1].

*Corresponding author; E-mail: oyanov74@mail.ru 
However, only a small part of infected people develop disease, and the disease outcome is influenced by a combination of host, bacterial, and environmental factors [2]. It is important to determine the most prevalent genotypes in a specific region of human population to find a correlation between putative virulence genes and clinical outcome. In areas of high HP infection prevalence, this information may potentially help us to predict the patient's disease course.

$H P$ is a slow-growing Gram-negative curved or S-shaped rod with a single tuft of multiple-polar flagella and characteristic terminal bulb. The organism does not form spores but, under adverse conditions, undergoes transformation from spiral to coccoid morphology often accompanied by a loss of culturability on conventional media. The organism is fastidious and cultivation in vitro requires a microaerophilic environment and complex media.

The core and pan genomes of $H P$ were studied by Cao et al. [3] that compared $75 H P$ genomes and found an open and diverse core genome with 1,173 conserved protein families and 673 conserved protein domains in the Helicobacter genus.

Approximately $89 \%$ of the predicted open-reading frames are common to different strains, confirming $H P$ as a single species. A region containing $45 \%$ of $H P$ strain-specific open-reading frames, termed the plasticity zone, is present on the chromosomes, verifying that some strain variability exists. The plasticity zone in $H P$ exhibits great variability [4].

According to the literature, $H P$ studies have focused on two groups of bacterial virulence factors, such as the cag pathogenicity island (cagPAI) and the vacuolating cytotoxin $v a c A$. The $v a c A$ cytotoxin is a well-known $H P$ virulence factor with multiple cellular effects. Bacterial strains have revealed that the vacA gene differs in its signal sequence $(s 1 a, s 1 b, s 1 c$, or $s 2)$ and in its mid-region sequence $(m 1$ or $m 2)$. Its virulence function has been implicated in the pathogenesis of peptic ulceration and a number of gastroduodenal disorders [5-7].

The cagPAI of $H P$ is a $\sim 40 \mathrm{~kb}$ region of chromosomal DNA that contains $\sim 27$ Cag proteins, whose part of them encodes components of a bacterial type-IV secretion system (T4SS). One of the most studied putative virulence factors is the CagA protein, encoded by the $\operatorname{cag} A$ gene. Some $H P$ strains contain only parts of the $\operatorname{cag} P A I$ and not the whole set of 27 genes [8]. The combination of $\operatorname{cag} P A I$ genes can also have an effect on the $H P$ virulence and the clinical outcome.

The aim of this study was to evaluate the prevalence of $H P$ genotypes ( $v a c A$ and cagPAI) directly in gastric biopsy specimens in patients with gastric diseases in Belarus. 


\section{Material and Methods}

Gastric biopsies were collected from 461 patients (average age of 42.9 years, 269 women and 192 men) with different gastrointestinal disorders in the medical center "Nordin" (Minsk, Belarus) from 2013 to 2015. All patients signed an informed consent form.

The specimens were examined for the presence of $H P$ by polymerase chain reaction (PCR). Based on endoscopic and histological findings, 287 patients presented superficial gastritis (SG), 59 had atrophy gastritis (AG), 47 had erosive gastritis (EG), 54 had duodenal ulcer disease (DU), and 14 patients were diagnosed to have stomach ulcer (SU).

Total DNA was extracted from frozen gastric biopsy specimens by DNA-sorbC (Apmlisens, Russia).

\section{HP genotyping}

A 267-bp fragment of the $23 S r R N A$ gene of $H P$ was amplified using primers HP-F and HP-R [9].

Gene amplification by PCR was prepared in a volume of $25 \mu \mathrm{l}$ containing $1 \times$ PCR buffer, $3 \mathrm{mM}$ of $\mathrm{MgCl}_{2}, 0.2 \mathrm{mM}$ of deoxynucleoside triphosphate, $0.5 \mathrm{U}$ of Taq polymerase, $10 \mathrm{pmol}$ of each primer, $1.5 \mu \mathrm{l}$ of DNA, and sterile distilled water. PCR amplifications were performed in an automated thermal cycler (Thercyc, Russia). All runs included a negative DNA control consisting of PCR grade water.

PCR-based genotyping was used to detect $s 1 a, s 1 b, s 2, m 1 a, m 1 b, m 2$, $\operatorname{cag} M$, cagA, and $\operatorname{cag} T$ genes (Table I) using previously published primers $[10,11]$.

Subsequently, DNA fragments were separated by electrophoresis on $1.2 \%$ agarose gel, stained with ethidium bromide, and visualized under UV transilluminator. Standards of 50 or $100 \mathrm{bp}$ (Life Technologies, Lithuania) were used as molecular size markers.

\section{Statistical analysis}

The $\chi^{2}$ test was applied to estimate the statistical differences between disease and various genotypes. The $p$ value $<0.05$ was considered as significant statistical differences. 
Table I. Primers used for $H P$ genotyping by PCR

\begin{tabular}{|c|c|c|}
\hline Gene & Primer sequence & $\begin{array}{c}\text { Size of the amplified } \\
\text { product (bp) }\end{array}$ \\
\hline \multirow[t]{2}{*}{$H P$} & F: 5'-AGGTTAAGAGGATGCGTCAGTC-3' & 267 \\
\hline & R: 5'-CGCATGATATTCCCATTAGCAGT-3' & \\
\hline \multirow[t]{2}{*}{ sla } & F: 5'-GTCAGCATCACACCGCAAC-3' & 190 \\
\hline & R: 5'-CTGCTTGAATGCGCCAAAC-3' & \\
\hline \multirow[t]{2}{*}{$s 1 b$} & F: 5'-AGCGCCATACCGCAAGAG-3' & 187 \\
\hline & R: 5'-CTGCTTGAATGCGCCAAAC-3' & \\
\hline \multirow[t]{2}{*}{$s 2$} & F: 5'-GCTAACACGCCAAATGATCC-3' & 199 \\
\hline & R: 5'-CTGCTTGAATGCGCCAAAC-3' & \\
\hline \multirow[t]{2}{*}{$m 1 a$} & F: 5'-GGTCAAAATGCGGTCATGG-3' & 290 \\
\hline & R: 5'-CTGTTAGTGCCCGCAGAAAC-3' & \\
\hline \multirow[t]{2}{*}{$m 1 b$} & F: 5'-GGCCCCAATGCAGTCATGGAT-3' & 295 \\
\hline & R: 5'-GCTGTTAGTGCCTAAAGAAGCAT-3' & \\
\hline \multirow[t]{2}{*}{$m 2$} & F: 5'-GGAGCCCCAGGAAACATTG-3' & 352 \\
\hline & R: 5'-CATAACTAGCGCCTTGCAC-3' & \\
\hline \multirow[t]{2}{*}{$\operatorname{cag} A$} & F: 5'-AATACACCAACGCCTCCAAG-3' & 400 \\
\hline & R: 5'-TTGTTGCCGCTTTTGCTCTC-3' & \\
\hline \multirow[t]{2}{*}{$\operatorname{cag} M$} & F: 5'-ACAAATACAAAAAAGAAAAAGAGGC-3' & 586 \\
\hline & R: 5'-ATTTTTCAACAAGTTAGAAAAAGCC-3' & \\
\hline \multirow[t]{2}{*}{$\operatorname{cag} T$} & F: 5'-CCATGTTTATACGCCTGTGT-3' & 301 \\
\hline & R: 5'-CATCACCACACCCTTTTGAT-3' & \\
\hline
\end{tabular}

Note: HP: Helicobacter pylori; PCR: polymerase chain reaction; F: forward; R: reverse.

\section{Results}

Studied population

A total of 461 patients were studied [192 men (41.6\%) and 296 women $(58.4 \%)$, aged between 22 and 84 years with mean age of $43.0 \pm 0.7$ years. Analysis showed that $64.9 \%$ of patients were $H P$-infected $(41.8 \%$ of men vs. $58.2 \%$ of women).

The histological data exhibited a significantly higher degree of inflammation (78\%) and neutrophil activity $(50.3 \%)$ in $H P$-positive patients $(p<0.05)$.

The clinical examination shows (Table II) that, among $H P$-positive, $11 \%$ patients have AG, $57.8 \%$ have $\mathrm{SG}, 10.4 \%$ have $\mathrm{EG}, 17 \%$ have DU, and $3.7 \%$ have SU. The analysis shows a significant increase in the number of people with DU among $H P$-positive patients; the risk of the disease increases by 10.8 times $(p<0.05,95 \% \mathrm{CI}=-3.2$ to 44.5$)$.

Figure 1 shows the comparison of the frequency of $H P$ infection between groups depending on age and clinical outcome. 
Table II. The frequency of $H P$ infection between groups depending upon age and clinical diagnosis

\begin{tabular}{lccr}
\hline \multirow{2}{*}{ Groups of patients } & \multicolumn{2}{c}{$H P$ detection } & Total (\%) \\
\cline { 2 - 3 } & Negative (\%) & Positive (\%) & 41.6 \\
Men & 41.4 & 41.8 & 58.4 \\
Women & 58.6 & 58.2 & 65.9 \\
Age & & & 34.1 \\
$<50$ years & 59.9 & 69.2 & 12.8 \\
$>50$ years & 40.1 & 30.8 & 62.3 \\
Morphological diagnosis & & & 10.2 \\
Atrophy gastritis (AG) & 16.0 & 57.8 & 11.7 \\
Superficial gastritis (SG) & 70.4 & 10.4 & 3.0 \\
Erosive gastritis (EG) & 9.8 & $17.1 *$ & 3.7 \\
Duodenal ulcer disease (DU) & 1.9 & & \\
Stomach ulcer (SU) & 1.9 & & \\
\hline Note: HP: Helicobacter pylori & & & \\
\hline
\end{tabular}

Note: HP: Helicobacter pylori.

* Significant in comparison with $H P$-negative group, $p<0.05$.

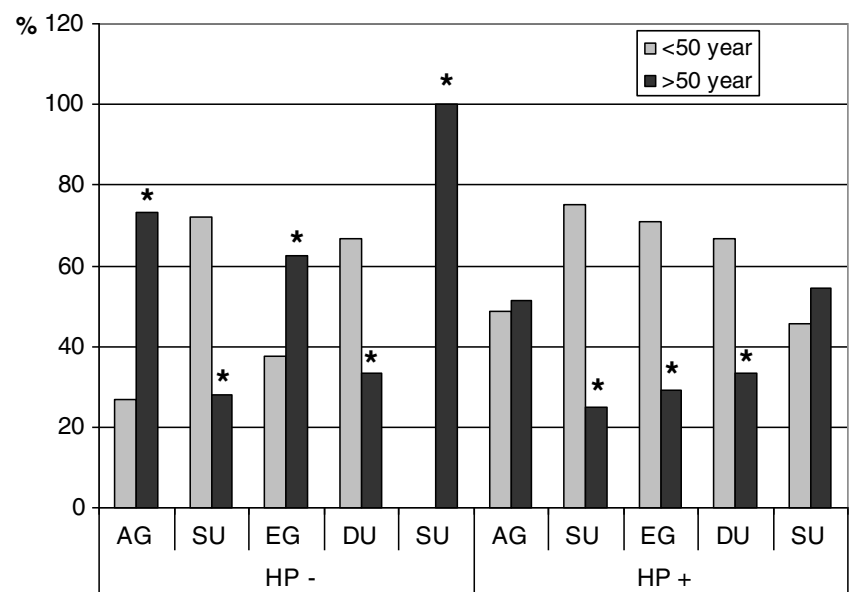

Figure 1. Distribution of $H P$-positive patients in different clinical outcome groups depending upon age. SG: superficial gastritis; AG: atrophy gastritis; EG: erosive gastritis; DU: duodenal ulcer; SU: stomach ulcer. *Significant in comparison with group $<50$ years, $p<0.05$

Among the patients less than 50 years of age, SG dominated $(p<0.01)$ regardless of $H P$ status (significantly higher than patients $>50$ years of age, $p<0.01)$.

In the group of $H P$-negative patients with $\mathrm{AG}$ and $\mathrm{EG}$, an increase in the number of people over the age of 50 years was found. In group with AG in the 
presence of $H P$ infection, an increase in the number of patients less than 50 years of age is observed.

Thus, the presence of $H P$ is a risk factor for developing AG in younger age people. Among $H P$-positive patients, a significant increase in the percentage of people with EG and DU in a group less than 50 years is observed. In the group of $H P$-negative patients with gastric ulcer, an increase in the number of individuals less than 50 years was not detected. In the detection of $H P$, the incidence of gastric ulcer in this group was $45.5 \%$.

Pathogenicity genes detection frequency in HP-positive patients' gastric biopsies

The presence of the pathogenicity genes was examined in all 299 $H P$-positive biopsies from patients with gastrointestinal diseases (Figure 2).

The predominant $v a c A$ genotype in the biopsies was the sla $(60.5 \%)$, followed by $m 2(47.1 \%)$ and $m l a(37.5 \%)$. The HP vacA sla/mla genotype was predominantly detected in our samples (28\%). Genotypes $s 1 a / m 2$ and $s 2 m 2$ were almost equally present, i.e., $24 \%$ and $21 \%$, respectively. In this study, the rare $s 2 \mathrm{mla}$ and $s 2 / \mathrm{ml}$ genotypes were detected in $4 \%$ and $1.3 \%$, respectively.

The cagA gene was observed in 202 of 299 (67.6\%) biopsies, and cagT and cagM detected with frequencies of $47.5 \%(142 / 299)$ and $35.8 \%(107 / 299)$, respectively. A significant correlation between the simultaneous presence of $\operatorname{cag} A$, $\operatorname{cag} M$, and $\operatorname{cag} T$ genes was found $(p<0.0001)$.

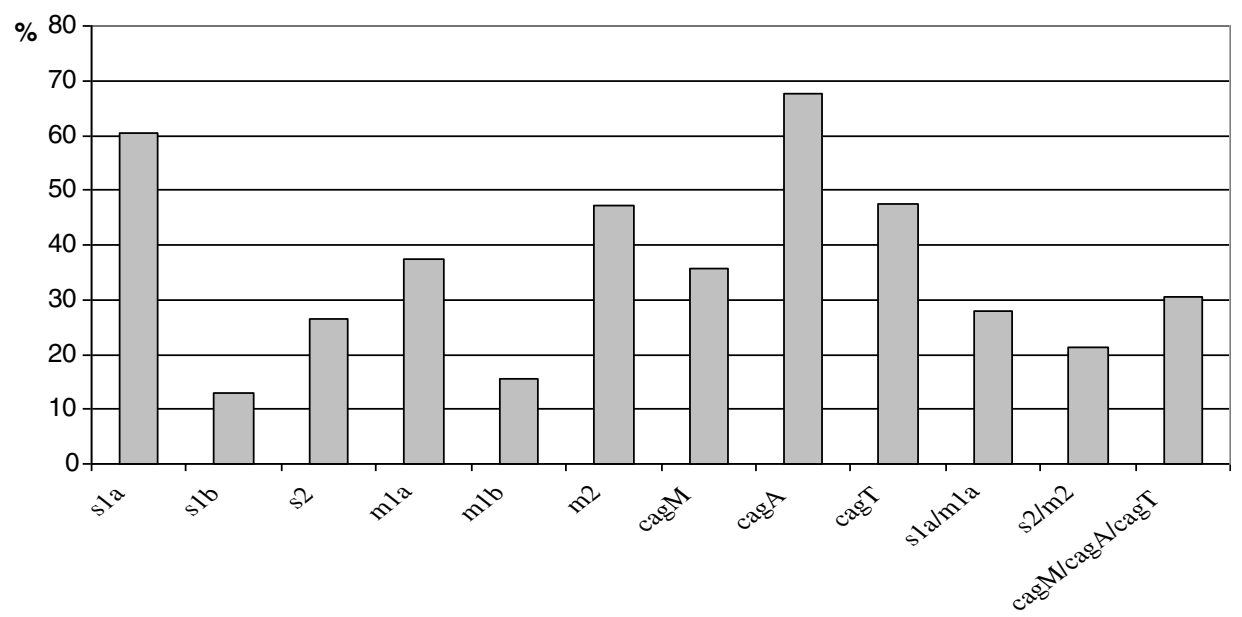

Figure 2. Distribution of genotypes for all $H P$-positive samples 
The most of $\operatorname{cag} A$-positive samples possessed the $s 1 a$ form of $v a c A$ gene (73.3\%), whereas among cag $A$-negative samples, only $14.8 \%$ contained sla vacA. The analysis showed that combination of three cagPAI genes (cagA, cagM, and cag $T$ ) was found in $30.4 \%$ samples.

\section{Relationship between HP genotypes and clinical outcomes}

The genotypes of $H P$ found in patients with different gastrointestinal diseases are presented in Table III.

Statistical comparative analysis of the frequency of each allele in the different form of disease revealed an association between allele sla and the presence of $\mathrm{AG}(p<0.05, \mathrm{OR}=3.7,95 \% \mathrm{CI}=1.4-10.0)$, EG $(p<0.05$, $\mathrm{OR}=2.4,95 \% \mathrm{CI}=1.0-6.1)$, and $\mathrm{DU}(p<0.02, \mathrm{OR}=3.2,95 \% \mathrm{CI}=1.5-7.1)$. The $v a c A$ s $1 b$ genotype was detected only in $12 \%$ of 299 patients: $9.1 \%$ with AG, $17.3 \%$ with SG, $3.2 \%$ with EG, and $7.8 \%$ with DU.

The association of middle $v a c A$ regions with clinical outcomes shows that $m l a$ allele was more frequently identified in patients with DU (53\%). There were no differences in $m 1 b$ allele between all clinical groups, whereas $m 2$ was the most predominant genotype in patients with SG and EG.

Table III. Association of HP genotypes with clinical diagnosis

\begin{tabular}{|c|c|c|c|c|c|}
\hline \multirow[b]{2}{*}{ Allele/gene } & \multicolumn{5}{|c|}{ Clinical diagnosis } \\
\hline & $\mathrm{AG}[n(\%)]$ & SG $[n(\%)]$ & $\mathrm{EG}[n(\%)]$ & $\mathrm{DU}[n(\%)]$ & $\mathrm{SU} n(\%)]$ \\
\hline sla & $26(78.8)^{*}$ & $86(49.7)$ & $22(71)^{*}$ & $39(76.5)^{*}$ & $8(72.7)$ \\
\hline$s 1 b$ & $3(9.1)$ & $30(17.3)$ & $1(3.2)$ & $4(7.8)$ & 0 \\
\hline$s 2$ & $4(12.1)$ & $57(33)$ & $8(25.8)$ & $8(15.7)$ & $3(27.3)$ \\
\hline$m 1 a$ & $13(39.4)$ & $58(33.5)$ & $10(32.3)$ & $27(53)^{*}$ & $4(36.4)$ \\
\hline$m 1 b$ & $5(15.1)$ & $28(16.2)$ & $5(16.1)$ & $6(11.8)$ & $2(18.2)$ \\
\hline$m 2$ & $15(45.5)$ & $87(50.3)$ & $16(51.6)$ & $18(35.2)$ & $5(45.4)$ \\
\hline sla/mla & $12(36.4)$ & $37(21.4)$ & 9 (29) & $23(45.1)^{*}$ & $3(27.3)$ \\
\hline$s 2 / m 2$ & $3(9.1)$ & $44(25.4)$ & $8(25.8)$ & $6(11.8)$ & $3(27.3)$ \\
\hline$s 1 a / m 2$ & $12(36.4)$ & $38(22)$ & $9(29)$ & $11(21.6)$ & $2(18.2)$ \\
\hline$s 2 / m 1 a$ & 0 & $8(4.6)$ & 0 & 0 & 0 \\
\hline $\operatorname{cag} M$ & $17(51.5)^{*}$ & $48(27.7)$ & $8(25.8)$ & $30(58.8)^{*}$ & $4(36.4)$ \\
\hline $\operatorname{cag} A$ & $25(75.8)^{*}$ & $96(55.5)$ & $26(83.9)^{*}$ & $46(90.2)^{*}$ & $10(90.1)^{*}$ \\
\hline $\operatorname{cag} T$ & $17(51.5)$ & $62(35.8)$ & $15(48.4)$ & $41(80.4)^{*}$ & $7(63.6)$ \\
\hline \multicolumn{6}{|l|}{ Gene combination } \\
\hline $\operatorname{cag} M / \operatorname{cag} A / \operatorname{cag} T$ & $13(39.4)$ & $39(22.5)$ & $8(25.8)$ & $29(56.9)^{*}$ & $2(18.2)$ \\
\hline sla/cagM/cagA/cagT & $12(36.4)$ & $32(18.5)$ & $8(25.8)$ & 25 (49) & $1(9.1)$ \\
\hline
\end{tabular}

Note: SG: superficial gastritis; AG: atrophy gastritis; EG: erosive gastritis; DU: duodenal ulcer; SU: stomach ulcer.

* Significant difference in comparison with SG group, $p<0.05$. 
Genotype $s 1 a / m 1 a$ was significantly found predominantly in patients with DU $(p=0.002, \mathrm{OR}=3.0,95 \% \mathrm{CI}=1.5-6.1)$. Although in this study, sla/m1a alleles were also more prevalent in $H P$ samples in patients with AG (36.4\%), but the results showed no statistical significance.

More than $20 \%$ of the SG, EG, and SU patients were infected with $s 2 m 2$ genotype bacteria. However, no significant correlation was observed between this virulence marker and disease status.

In this study, the $\operatorname{cag} A$ gene was found with a high incidence in most patients with inflammatory diseases of the stomach and duodenum: $75.8 \%$ in cases of AG, $83.9 \%$ - EG, $90.2 \%$ - DU, and $90.1 \%$ in cases of gastric ulcer. Simultaneously, there was a significant increase in the frequency of $\operatorname{cag} T$ in patients with DU as compared to $\mathrm{SG}(p<0.001, \mathrm{OR}=7.3,95 \% \mathrm{CI}=3.2-16.8)$. A high $\operatorname{cag} M$ prevalence was also found in patients with AG and DU diseases.

The analysis of the data showed that in the biopsy samples obtained from patients with DU, all three island genes of pathogenicity of cagPAI are reliably more often detected in comparison with SG patients $-56.9 \%$ vs. $22.5 \%$, which increases the risk of developing DU by 4.5 times ( $\mathrm{OR}=4.5,95 \% \mathrm{CI}=2.2-9.2)$.

The combination $s$ la/cagM/cagA/cagT was detected in $49 \%(p=0.001$, $\mathrm{OR}=4.2,95 \% \mathrm{CI}=2.1-8.7)$ and $36.4 \%(p=0.05, \mathrm{OR}=2.5,95 \% \mathrm{CI}=1.0-6.1)$ of patients with PU and $\mathrm{AG}$, respectively.

\section{Discussion}

Gastric and systemic immune responses develop within a short period of time after $H P$ infection. The gastric inflammatory response induced by $H P$ consists of neutrophils, lymphocytes, plasma cells, dendritic cells, and macrophages, along with varying degrees of epithelial cell degeneration and injury [12]. Contact between $H P$ and gastric epithelial cells results in activation of NF- $\mathrm{BB}$, which is followed by increased interleukin-8 (IL-8) expression [13]. IL-18 is essential for inducing $\mathrm{CD} 4+\mathrm{CD} 25+\mathrm{FOXP} 3+$ regulatory $\mathrm{T}$ cell in response to $H P$, which in turn restricts excessive effector T-cell activation and promotes infection persistence [14].

After entering the host mucosa stomach, $H P$ utilizes its urease activity to neutralize the hostile acidic condition at the onset of infection. Then, HP use flagella-mediated motility to move toward host gastric epithelium cells. Finally, $H P$ releases several effector proteins/toxins causing host tissue damage [7].

Differences in the prevalence of $H P$ genotypes could play a role in the incidence diseases. This study analyzed the association between gastric mucosa pathology and HP genotypes. 
VacA is a key toxin for HP pathogenesis. VacA is bound to cell surface and initiates a pro-inflammatory response. It modulates $\mathrm{T}$ - and B-cell activation and proliferation, and if the toxin is transported to the mitochondria, it induces apoptosis [15]. The vacA gene is present in all HP strains and comprises variable regions (signal $-\mathrm{s}$, middle $-\mathrm{m}$, and intermediate $-\mathrm{i}$ ).

The vacA signal region encodes the $\mathrm{N}$ terminus of the toxin and may be active (type $s 1$ ) or encode an N-terminal extension, which blocks activity (type $s 2$ ). The vacA mid-region may bind to a wide range of cells, causing toxicity (type $m 1$ ) or to a smaller range (type $m 2$ ) [7]. Genotypic combination of vacA alleles results in different pathogenicity level as follows: slaml produces high amount of toxin and consequently the most virulent, $s 1 m 2$ - produces moderate vacuolating toxins [11].

Conclusions about any association between the presence of $H P$ genotypes and clinical outcome may not be true because there is a geographic variability of $H P$ genotypes [16, 17]. It is important to determine the most prevalent genotypes in a specific region and to confirm whether there is a correlation between putative virulence genes and diseases. According to the literature, the vacA sla allele is found most predominantly in Northern and Eastern European strains, whereas $s 1 b$ is prevalent in Latin America [18-20].

It is known that patients with the vacA sla gene had a significantly more strong degree of chronic inflammation, whereas those with vacA $s 2$ had significantly less activity inflammation [21, 22].

In agreement with other studies, we confirmed that the most determinated $v a c A$ allele is sla [22-24] and less common is allele mla. Our findings demonstrate an association between the presence of the $s / a$ allele and the presence of AG, EG, and DU. The explanation for these results may be stated that HP strains with the $s$ la genotype produce more vacuolating toxin and might contribute to the more effective development of inflammation.

Atherton et al. [25] demonstrated that mla alleles are associated with gastric epithelial injury. Our results also demonstrate an association between the presence of the $m l a$ allele and presence of DU.

We found that the frequency of the genotype $s 1 a / m 1 a$ vacA gene in patients with chronic SG was $21.4 \%$; it is significantly lower compared with the group of patients with DU $-45.1 \%(p<0.05, \mathrm{OR}=3.0,95 \% \mathrm{CI}=1.5-6.1)$.

The cagPAI is one of the important virulence determinants of HP. The cagPAI encodes 27-31 proteins and comprises two regions - cagI and cagII. The cagPAI genes encode a T4SS that forms a structure to translocate the $\operatorname{cag} A$ protein into the gastric epithelial cells. In addition, the cagPAI stimulates the release of pro-inflammatory cytokines in gastric mucosa, including IL-8 [8]. 
In this investigation, the $\operatorname{cag} A$ and $\operatorname{cag} M$ were selected to represent $c a g I$, and $\operatorname{cag} T$ was selected to represent $\operatorname{cag} I I$.

The primary virulence determinant of $H P$ is CagA oncoprotein, which is associated with development of severe outcomes of the infection [26]. When CagA protein is introduced into a host cell, toxic change leads to abnormal proliferation, motility, and cytoskeletal change in gastric epithelial cells [27].

In European studies of $H P$ strains, the frequency of $\operatorname{cag} A$ has shown variations $(72 \%-81 \%)$ and has been higher in southeast European countries (Bulgaria, Greece, and Turkey) [18, 28, 29]. A high cagA gene frequency $(86 \%-87 \%)$ is observed in East Asia [30, 31]. The results of this study also showed that the prevalence of $\operatorname{cag} A$ is significantly higher among different disease groups in comparison with SG group $(p<0.05)$. The highest percentage is observed in patients with ulcer $(90.2 \%)$.

The $\operatorname{cag} T$ is located at the $3^{\prime}$ end of the cagII region. Studies showed that strains lacking the $\operatorname{cag} T$ gene had a defective "molecular syringe" that is encoded by the PAI [32], thus reflecting on inability of the type-IV system to eject out the $\operatorname{cag} A$ protein. Our results show that the prevalence of $\operatorname{cag} T$ was significantly different in patients with DUs compared with those with non-ulcer dyspepsia and it is a better marker than the $\operatorname{cag} A$ status for ulcer clinical outcome. Other studies conducted elsewhere also support our findings; in England, Kauser et al. [19] found an association between cagT and ulcer development.

We found a significant correlation between the simultaneous presence of $\operatorname{cag} P A I$ genes in the samples studied. It was found that combination $\operatorname{cagM/\operatorname {cag}A/}$ $\operatorname{cag} T$ is detected more frequently in patients with peptic ulcer than in patients with chronic gastritis. The data show the significant roles of CagT and CagM in the T4SS effectivity in $H P$-host interaction that results in an enhanced ability of the bacterium to colonize the antral gastric niche.

This study analyzed the relationship between $H P$ genotypes and clinical data of gastrointestinal diseases. The results presented in this study show that the $H P$ samples from patients suffering DU had a high expression of sla/mla genotype $(45.1 \%)$. We conclude that genotyping of $H P$ (cagPAI) may be useful in clinical practice for identifying patients with a high risk of developing gastric diseases.

We think that the prevalence of virulence-associated $H P$ genotypes has clinical implications for our understanding of the pathogenesis of infection and related gastric disorders. In future studies, it would be of interest to evaluate the influence of other pathogenicity genes in helicobacteriosis clinical outcome. 


\section{Conflict of Interest}

The authors declare no conflict of interest.

\section{References}

1. International Agency for Research on Cancers. Monographs on the Evaluation of Carcinogenic Risks to Humans. World Health Organization, Geneva, 1994, p. 61.

2. Atherton, J. C., Blaser, M. J.: Coadaptation of Helicobacter pylori and humans: Ancient history, modern implications. J Clin Invest 119, 2475-2487 (2009).

3. Cao, D. M., Lu, Q. F., Li, S. B., Wang, J. P., Chen, Y. L., Huang, Y. Q., Bi, H. K.: Comparative genomics of H. pylori and non-pylori Helicobacter species to identify new regions associated with its pathogenicity and adaptability. Biomed Res Int 2016, 6106029 (2016).

4. Thorell, K., Lehours, P., Vale, F. F.: Genomics of Helicobacter pylori. Helicobacter 22 , e12409 (2017).

5. Backert, S., Neddermann, M., Maubach, G., Naumann, M.: Pathogenesis of Helicobacter pylori infection. Helicobacter 21, 19-25 (2016).

6. Salama, N. R., Hartung, M. L., Müller, A.: Life in the human stomach: Persistence strategies of the bacterial pathogen Helicobacter pylori. Nat Rev Microbiol 11, 385-399 (2013).

7. Kao, C. Y., Sheu, B. S., Wu, J. J.: Helicobacter pylori infection: An overview of bacterial virulence factors and pathogenesis. Biomed J 39, 14-23 (2016).

8. Merino, E., Flores-Encarnación, M., Aguilar-Gutiérrez, G. R.: Functional interaction and structural characteristics of unique components of Helicobacter pylori T4SS. FEBS J 284, 3540-3549 (2017).

9. Oleastro, M., Menard, A., Santos, A., Lamouliatte, H., Monteiro, L., Barthelemy, Ph., Megraud, F.: Real-time PCR assay for rapid and accurate detection of point mutations conferring resistance to clarithromycin in Helicobacter pylori. J Clin Microbiol 41, 397-402 (2003).

10. Atherton, J. C., Cao, P., Peek, R. M. Jr., Tummuru, M. K., Blaser, M. J., Cover, T. L.: Mosaicism in vacuolating cytotoxin alleles of Helicobacter pylori. Association of specific vacA types with cytotoxin production and peptic ulceration. J Biol Chem 270, 1777117777 (1995).

11. Strobel, S., Bereswill, S., Balig, P., Allgaier, P., Sonntag, H. G., Kist, M.: Identification and analysis of a new vacA genotype variant of Helicobacter pylori in different patient groups in Germany. J Clin Microbiol 36, 1285-1289 (1998).

12. White, J. R., Winter, J. A., Robinson, K.: Differential inflammatory response to Helicobacter pylori infection: Etiology and clinical outcomes. J Inflamm Res 8, 137-147 (2015).

13. Alzahrani, Sh., Lina, T., Gonzalez, J., Pinchuk, I., Beswick, E., Reyes, V.: Effect of Helicobacter pylori on gastric epithelial cells. World J Gastroenterol 20, 12767-12780 (2014). 
14. Oertli, M., Sundquist, M., Hitzler, I., Engler, D. B., Arnold, I. C., Reuter, S., Maxeiner, J., Hansson, M., Taube, Ch., Quiding-Järbrink, M., Müller, A.: DC-derived IL-18 drives Treg differentiation, murine Helicobacter pylori-specific immune tolerance, and asthma protection. J Clin Invest 122, 1082-1096 (2012).

15. Isomoto, H., Moss, J., Hirayama, T.: Pleiotropic actions of Helicobacter pylori vacuolating cytotoxin, VacA. Tohoku J Exp Med 220, 3-14 (2010).

16. Yamaoka, Y., Kodama, T., Gutierrez, O., Kim, J. G., Kashima, K., Graham, D. Y.: Relationship between Helicobacter pylori iceA, cagA, and vacA status and clinical outcome: Studies in four different countries. J Clin Microbiol 37, 2274-2279 (1999).

17. Kolayli, F., Karadenizli, A., Bingöl, R., Schneider, T., Kist, M.: Differences of vacA alleles and cagA gene positivity of Helicobacter pylori strains isolated from two different countries: Turkey and Germany. Mikrobiyol Bul 46, 332-334 (2012).

18. Boyanova, L., Markovska, R., Yordanov, D., Marina, M., Ivanova, K., Panayotov, S., Gergova, G., Mitov, I.: High prevalence of virulent Helicobacter pylori strains in symptomatic Bulgarian patients. Diagn Microbiol Infect Dis 64, 374-380 (2009).

19. Kauser, F., Hussain, M. A., Ahmed, I., Srinivas, S., Devi, S. M., Majeed, A. A., Rao, K. R., Khan, A. A., Sechi, L. A., Ahmed, N.: Comparative genomics of Helicobacter pylori isolates recovered from ulcer disease patients in England. BMC Microbiol 25, 32 (2005).

20. Con, S. A., Takeuchi, H., Valerín, A. L., Con-Wong, R., Con-Chin, G. R., Con-Chin, V. G., Nishioka, M., Mena, F., Brenes, F., Yasuda, N., Araki, K., Sugiura, T.: Diversity of Helicobacter pylori cagA and vacA genes in Costa Rica: Its relationship with atrophic gastritis and gastric cancer. Helicobacter 12, 547-552 (2007).

21. Basso, D., Zambon, C. F., Letley, D. P., Stranges, A., Marchet, A., Rhead, J. L., Schiavon, S., Guariso, G., Ceroti, M., Nitti, D., Rugge, M., Plebani, M., Atherton, J. C.: Clinical relevance of Helicobacter pylori cagA and vacA gene polymorphisms. Gastroenterology 135, 91-99 (2008).

22. Almeida, N., Donato, M. M., Romãozinho, J. M., Luxo, C., Cardoso, O., Cipriano, M. A., Marinho, C., Fernandes, A., Sofia, C.: Correlation of Helicobacter pylori genotypes with gastric histopathology in the central region of a South-European country. Dig Dis Sci 60, 74-85 (2015).

23. Markovska, R., Boyanova, L., Yordanov, D., Stankova, P., Gergova, G., Mitov, I.: Status of Helicobacter pylori cag pathogenicity island (cagPAI) integrity and significance of its individual genes. Infect Genet Evol 59, 167-171 (2018).

24. Andreson, H., Loivukene, K., Sillakivi, T., Maaroos, H. I., Ustav, M., Peetsalu, A., Mikelsaar, M.: Association of $\operatorname{cag} A$ and vacA genotypes of Helicobacter pylori with gastric diseases in Estonia. J Clin Microbiol 40, 298-300 (2002).

25. Atherton, J. C., Peek, R. M., Tham, K. T., Cover, T. L., Blaser, M. J.: Clinical and pathological importance of heterogeneity in $v a c A$, the vacuolating cytotoxin gene of Helicobacter pylori. Gastroenterology 112, 92-99 (1997).

26. Park, J. Y., Forman, D., Waskito, L. A., Yamaoka, Y., Crabtree, J. E.: Epidemiology of Helicobacter pylori and CagA-positive infections and global variations in gastric cancer. Toxins (Basel) 10, 163 (2018).

27. Hatakeyama, M.: Oncogenic mechanisms of the Helicobacter pylori CagA protein. Nat Rev Cancer 4, 688-69 (2004).

28. Apostolopoulos, P., Vafiadis-Zouboulis, I., Tzivras, M., Kourtessas, D., Katsilambros, N., Archimandritis, A.: Helicobacter pylori (H. pylori) infection in Greece: The changing 
prevalence during a ten-year period and its antigenic profile. BMC Gastroenterol 16, 11 (2002).

29. Caner, V., Yilmaz, M., Yonetci, N., Zencir, S., Karagenc, N., Kaleli, I., Bagci, H.: H. pylori iceA alleles are disease-specific virulence factors. World J Gastroenterol 13, 2581-2585 (2007).

30. Pinto-Ribeiro, I., Ferreira, R. M., Batalha, S., Hlaing, T., Wong, S. I., Carneiro, F., Figueiredo, C.: Helicobacter pylori vacA genotypes in chronic gastritis and gastric carcinoma patients from Macau, China. Toxins (Basel) 8, E142 (2016).

31. Aziz, F., Chen, X., Yang, X., Yan, Q.: Prevalence and correlation with clinical diseases of Helicobacter pylori cagA and vacA genotype among gastric patients from Northeast China. Biomed Res Int 2014, 142980 (2014).

32. Johnson, E. M., Gaddy, J. A., Voss, B. J., Hennig, E. E., Cover, T. L.: Genes required for assembly of pili associated with the Helicobacter pylori cag type IV secretion system. Infect Immun 82, 3457-3470 (2014). 